Article

\title{
Farmers' Knowledge on Pesticide Safety and Pest Management Practices: A Case Study of Vegetable Growers in Chitwan, Nepal
}

\author{
Jhalendra P. Rijal ${ }^{1, *(D)}$, Rajendra Regmi ${ }^{2}$, Rajan Ghimire ${ }^{3}\left(\mathbb{D}\right.$, Krishna D. Puri ${ }^{4}$ (D), \\ Sudan Gyawaly ${ }^{5}$ and Sujata Poudel ${ }^{6}$ \\ 1 University of California Cooperative Extension \& Statewide IPM Program, Modesto, CA 95358, USA \\ 2 Department of Entomology, Agriculture and Forestry University, Rampur, Chitwan 44209, Nepal; \\ rregmi@afu.edu.np \\ 3 Agricultural Science Center, New Mexico State University, Clovis, NM 88101, USA; rghimire@nmsu.edu \\ 4 Department of Plant Pathology, University of California-Davis, Davis, CA 95616, USA; kdpuri@ucdavis.edu \\ 5 Department of Natural Resources and Environmental Design, North Carolina A \& T State University, \\ Greensboro, NC 27411, USA; sgyawaly@ncat.edu \\ 6 Nepal Agricultural Research Council, Government of Nepal, Khumaltar, Lalitpur 44700, Nepal; \\ sujatapoudel40@gmail.com \\ * Correspondence: jrijal@ucdavis.edu; Tel.: +1-209-525-6800
}

Received: 18 December 2017; Accepted: 16 January 2018; Published: 22 January 2018

\begin{abstract}
Farmers' knowledge on pesticides and their safe use are critical for implementing effective pest management program. A household survey was conducted using the semi-structured questionnaire to evaluate vegetable growers' knowledge on pesticide safety and pest management practices in Nepal. Results indicated that chemical pesticides were the primary choice of over $80 \%$ growers for pest management. Notably, $90 \%$ growers were aware of adverse effects of pesticides on human health and to the environment. Over $84 \%$ growers used at least one form of personal protection equipment (PPE) during pesticide spray or handling, although the quality and appropriateness of the PPE warrants further investigation. Nearly $17 \%$ growers received at least one short-term training on integrated pest management (IPM); however, all of them neither knew the harmful effects of pesticide residues nor practiced proper pesticide disposal methods. Over $90 \%$ of growers rely on local pesticide retailers (i.e., Agro-vets) for technical know-how about pesticide selection, handling, and use. This study highlighted a need for immediate implementation of strict pesticide use regulations and recommended educational programs for pest control professionals, growers, and pesticide retailers.
\end{abstract}

Keywords: pesticide exposure; IPM; personal protective equipment; Nepal

\section{Introduction}

Developing countries have been experiencing a significant shift in food consumption habits in recent decades. The relative importance of high-value commodities including vegetables is steadily increasing in South Asia in recent years [1]. Fresh vegetable production in Nepal has increased at an average annual rate of $6.9 \%$ between the year 2000 and 2010, with an increased production area by $5 \%$ [2]. Fresh vegetable production in 2014 occupied approximately 254,932 ha area of Nepal with a total vegetable production of 3,421,035 metric tons [3]. The per capita vegetable consumption of Nepal increased from $60 \mathrm{~kg}$ to $105 \mathrm{~kg}$ in last two decades [2]. However, fruit and vegetable consumption in Nepal is still below the WHO recommended level [4]. Chitwan district is one of the consistent vegetable suppliers for the major vegetable market of the country including the capital city, Kathmandu. The area under vegetable production in Chitwan has increased significantly in recent years. Currently, Chitwan 
is ranked third among major vegetable producing districts in Nepal, with an annual production of 87,560 metric tons from a 6369 ha area [3]. With this increase in vegetable production, there is also an increase in the use of production inputs such as chemical fertilizers and other plant nutrients, crop seeds, and pesticides.

Commercial vegetable production in Nepal heavily relies on chemical pesticides [5]. However, there is neither a comprehensive record of the amount of pesticide import and use in agriculture nor the effect of pesticides on human or environmental health [6]. A study reported an estimated annual import of 211 metric tons of pesticides, primarily fungicides (51.38\%), followed by insecticides $(29.19 \%)$ and herbicides (7.4\%) [7]. The southern plain region (Terai), also called the 'food basket' of the country, uses the highest amount of pesticide per unit area followed by the mid-hills and high-mountains regions [8]. With the increase in pesticide use, the associated potential risk to human health and the environment is a concern. Repeated use of single or limited pesticide active ingredients (a.i.), use of higher rates of pesticide than needed, and lack of user knowledge on pesticide type and toxicity are some of the current major issues associated with the pesticide use in Nepal [9]. Several chemical pesticides used in agriculture are known to cause health problems in human, livestock, and produce an adverse impact on plant diversity and environment in both short and long run $[6,10,11]$. Improper pesticide handling causes accidental poisoning, and even acute or chronic health effects [7]. In long run, pesticide exposure can cause long-lasting health issues such as dermatosis, cancer, and genotoxic, neurotoxic, and respiratory effects [12]. In developing countries, the use of outdated, non-patented, more toxic, and environmentally persistent pesticide are the leading causes of higher toxicity $[13,14]$. In addition, farmers in developing countries are exposed to toxic chemicals due to a lack of technical knowledge on toxicity levels of pesticides and safety measures to protect themselves from the exposure [6,12,15-17]. The improper handling of pesticide occurs mainly at the time of mixing and application, during storage, and during pesticide disposal $[7,18]$

There have been several studies conducted in past decades which have focused on the use of chemical pesticides in South Asia, and their consequences if handled improperly. One report in China indicated that majority of farmers were unaware of proper disposal of pesticides, and habituated to dispose in sensitive areas such as streams and rivers [18]. Many farmers in South Asian countries-including Pakistan, India, and Thailand—are using WHO-rated highly toxic and, in some cases, banned pesticides without knowing the consequences to their health and environment [19-21]. In Nepal, few studies have been conducted on pesticide use knowledge and practices. According to a household survey in Kavre district [6], one of the districts with intensive commercial agriculture reported that female members of the family were exposed more to pesticides than male because of their involvement in the vegetable production. In Chitwan, one case study was conducted to test the farmers' attitudes and knowledge about vegetable production and pest management, however, the study was focused only in one vegetable growing community [5]. Thus, a comprehensive work representing multiple vegetable production areas in the district is lacking. Our study was focused on evaluating the current status of pesticide use, and to assessing farmer knowledge on safe pesticide handling at six major commercial vegetable producing areas of the district. Such information will help in improving awareness to the farmers and related stakeholders such as agricultural technicians, and extension agents to conduct training or awareness programs for addressing specific needs.

\section{Materials and Methods}

\subsection{Study Area and Selection of Vegetable Growers}

The study was conducted in six commercial vegetable growing villages in the western Chitwan, Nepal in spring 2016. The study area was approximately $120 \mathrm{~km}$ southwest of the capital city, Kathmandu. The six villages are located within the 20-km radius from Rampur (GPS coordinates: $27^{\circ} 39^{\prime} 04.89^{\prime \prime} \mathrm{N}$ and $84^{\circ} 20^{\prime} 57.47^{\prime \prime} \mathrm{E}$ ), the central location of the study area (Figure 1). The area has tropical monsoon climate with high relative humidity throughout the year. The monsoon season starts 
in June and ends in September. The average temperatures of the study area during the hottest (May) and coldest (January) months are $29.2^{\circ} \mathrm{C}$ and $15.7^{\circ} \mathrm{C}$, respectively. Chitwan district is spread across an area of 223,839 ha and has a population of 472,048 . A total number of households in the district is 92,863 with an average household size being five people per family [22]. Nearly $35 \%$ of the total land is agricultural that includes pasture land, and $\sim 31 \%$ of the total population is engaged in agriculture [23]. Six farmer groups representing the six-major vegetable growing villages in western Chitwan were selected for the study. These farmer's groups (30 households in an individual group) were identified based on grower registration information of District Agriculture Development Office (DADO), Chitwan. All study areas were identified and listed as a pocket area for fresh vegetable production by DADO Chitwan. The vegetable production is seasonal, mainly follows the rice-vegetables-corn cropping rotation. The study area is close to the Agriculture and Forestry University, and highly accessible to all major cities linked to the central transportation system. Crucifers (cabbage, cauliflower), solanaceous (potato, tomato, eggplant, sweet pepper), and cucurbitaceous (cucumber, gourd, melons) crops are major vegetable crops grown in the area.

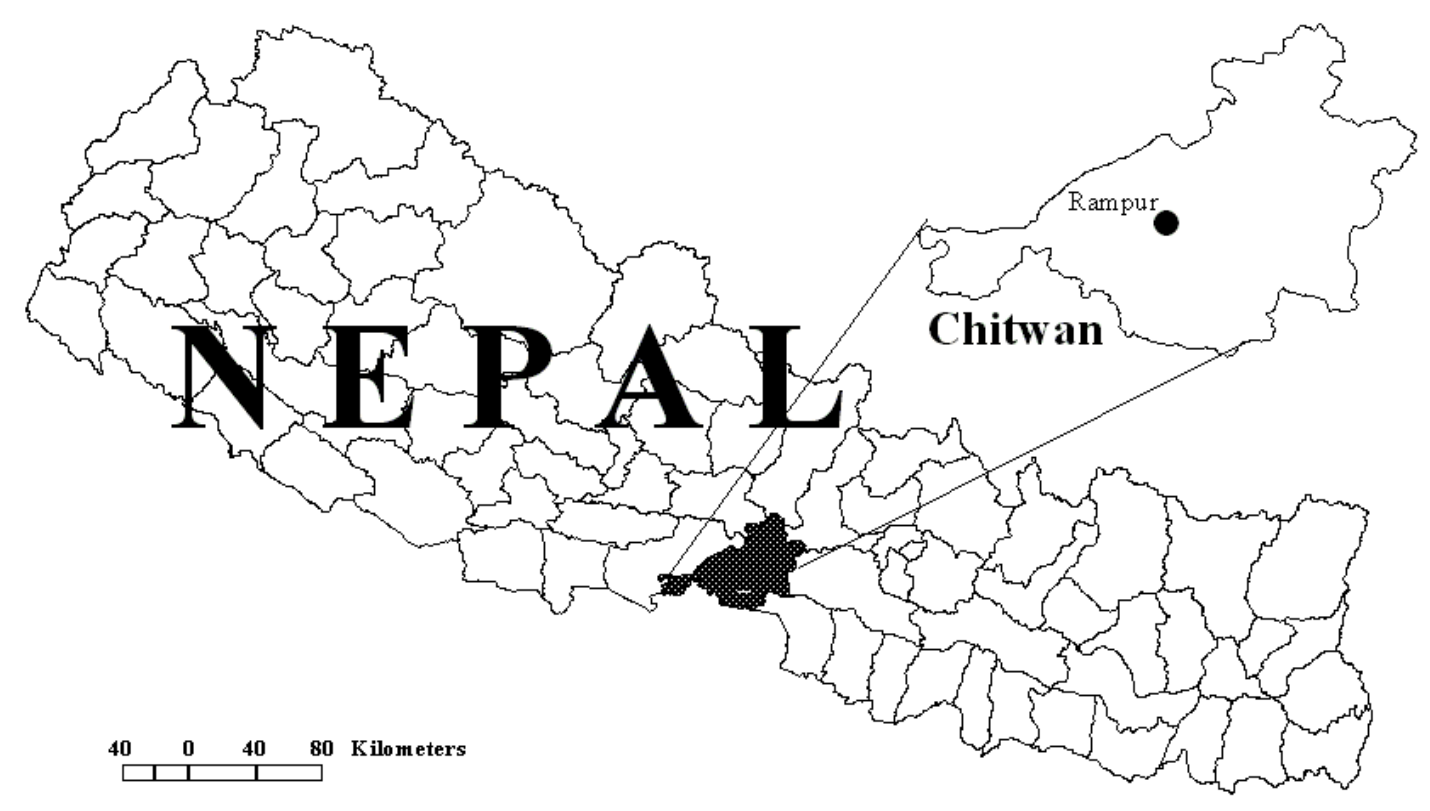

Figure 1. Study sites representing a major vegetable production pocket in Nepal.

\subsection{Survey Approach and Questionnaire Development}

This study is a part of an interdisciplinary project to identify pesticide use knowledge and practices among vegetable grower, and then conduct a training program to address those issues among selected farmers. Of total 180 farmers selected for training, by the Center for Agricultural Research and Development (CARD-Nepal), a total 100 farmers ( $56 \%$ of total study population) were administered with an informed consent questionnaire. The stratified random sampling ( 16 farmers from each of the first two groups; and 17 from each of the remaining four groups) was used to select respondent households. The key informants' survey was used for a sampling frame, and survey respondents were selected after a pre-field visit. The majority of respondents had long-standing experience in vegetable production. 
The semi-structured questionnaire (also referred to as a mixed questionnaire) consists of both closed and open-ended questions. The closed-ended questions have multiple options as answers and allow respondents to select a single option. The open-ended questions allow the participants to provide their answers without using any structured options. The questionnaire was first pretested with five households, adjusted as needed, and used to understand farmers' attitudes towards pesticide use, knowledge, and practices. The questionnaire was divided into three broad sections. The first section related to the socio-demographic questions to know the age, education level, income, landholding, purpose of agriculture, source of income, vegetable production experience, and other related information. The second section included current pest management practices and pesticide use patterns. The specific topics covered in this section included pest control methods, rates, and frequencies of pesticide use, decision-making on the selection of pesticide, spray timing, and other considerations. The third section included the technical know-how of farmers about pesticide safety and pesticide exposure issues such as understating the pesticide label, pesticide toxicity label, pesticide mode of action, pesticide residuals, pesticide resistance, and technical knowledge about integrated pest management (IPM).

\subsection{Data Analysis}

A descriptive statistics and frequency distribution analysis were conducted among all parameters obtained. A Chi-square test was used to determine an association between parameters in socio-demographic characteristics, pesticide use pattern, exposure, and other qualitative variables $(p<0.05)$. The software ver. 21 SPSS (IBM Corp., Armonk, NY, USA) and Microsoft Excel (Microsoft Corp., Redmond, WA, USA) were used in data analysis.

\section{Results and Discussion}

\subsection{Demography and Socioeconomic Status}

Majority of the respondent were of age group 41-60 followed by 21-40 years, above 60-years, and below 20-years (Table 1). Involvement of younger farmers (below 40 years old) in vegetable production provides a strong hope to train new and safer pest management techniques compared to the older farmers [24]. Of the surveyed farmers, more than $40 \%$ had a secondary level education (10th grade) followed by literate (27\%), illiterate (22\%), higher secondary (12th grade) $(7 \%)$, and university degree $(3 \%)$. More than $76 \%$ of the population considered agriculture as their primary occupation, of which $19 \%$ of them had another occupation besides agriculture. Fifty-eight percent of farmers responded that agriculture contributed more than $60 \%$ of their total annual income, while $11 \%$ responded that agriculture only contributed $20 \%$ of their annual income. Only $16 \%$ of farmers had a land holding of at least 1.33 ha, while $84 \%$ had less than 1.33 ha (Table 1 ). Of the farmers surveyed, about $86 \%$ grew vegetables for the commercial market, and the remaining $14 \%$ sold fresh vegetables in the local market or use for the family consumption. About half $(40 \%)$ of the farmers were growing vegetables commercially for more than 10 years, and $23 \%$ of growers had started recently (less than four years). 
Table 1. Socio-demographic status of surveyed vegetable growers in Chitwan, Nepal.

\begin{tabular}{|c|c|c|c|c|}
\hline \multicolumn{2}{|c|}{ Category } & \multirow[t]{2}{*}{ Frequency (\%) } & \multirow{2}{*}{$\begin{array}{c}\text { Chi Square } \\
41.36\end{array}$} & \multirow{2}{*}{$\begin{array}{r}p \text {-Value } \\
<0.001\end{array}$} \\
\hline Age (years) & & & & \\
\hline & Below 20 & 1 & & \\
\hline & $21-40$ & 34 & & \\
\hline & $41-60$ & 44 & & \\
\hline & Above 60 & 21 & & \\
\hline \multirow[t]{6}{*}{ Education level } & & & 47.6 & 0.001 \\
\hline & Illiterate & 22 & & \\
\hline & Literate & 27 & & \\
\hline & $\begin{array}{l}\text { Secondary (10th } \\
\text { grade) }\end{array}$ & 41 & & \\
\hline & $\begin{array}{l}\text { Higher secondary } \\
\text { (12th grade) }\end{array}$ & 7 & & \\
\hline & University degree & 3 & & \\
\hline \multirow[t]{5}{*}{ Income source } & & & 146.16 & 0.001 \\
\hline & Agriculture & 76 & & \\
\hline & Business & 1 & & \\
\hline & $\begin{array}{l}\text { Foreign } \\
\text { employment }\end{array}$ & 4 & & \\
\hline & More than one & 19 & & \\
\hline \multirow[t]{5}{*}{ Landholding (ha) } & & & 5.28 & 0.001 \\
\hline & $<0.33$ & 30 & & \\
\hline & $0.33-0.66$ & 24 & & \\
\hline & $0.66-1.33$ & 30 & & \\
\hline & $>1.33$ & 16 & & \\
\hline \multicolumn{2}{|c|}{ Agriculture share in total income (\%) } & & 59.6 & 0.001 \\
\hline & $<20$ & 11 & & \\
\hline & $20-40$ & 19 & & \\
\hline & $40-60$ & 12 & & \\
\hline & $>60$ & 58 & & \\
\hline \multirow[t]{4}{*}{ Purpose of agriculture } & & & 28.58 & 0.001 \\
\hline & Consumption & 14 & & \\
\hline & Commercial & 29 & & \\
\hline & Both & 57 & & \\
\hline \multicolumn{2}{|c|}{ Experience of vegetable production (years) } & & 12.72 & $<0.001$ \\
\hline & $1-3$ years & 23 & & \\
\hline & $4-7$ years & 20 & & \\
\hline & $7-10$ years & 17 & & \\
\hline & $>10$ years & 40 & & \\
\hline
\end{tabular}

\subsection{Current Pest Management Practices in Commercial Vegetable Production}

The majority of the farmers $(80 \%)$ used chemical pesticides solely to control insect pests in their vegetable crops. Only $16 \%$ of the farmers used other methods (biological, cultural, and mechanical) for insect pests control. A negligible number of the farmers depend on cultural (1\%), biological (1\%), or mechanical methods $(2 \%)$ as a standalone pest management method (Table 2$)$. High dependency on chemical pesticides in vegetable production was also reported in the Bara and Dhading districts of Nepal [25]. Vegetables being a high-value commodity, this trend is developing rapidly in most vegetable production areas in Nepal [26]. In contrast, only $11 \%$ of farmers used chemical pesticides in cereal crops (Table 2). This difference in pesticide use indicates that the traditional low-input farming system is still prevalent in staple food crops (rice, corn, wheat) production in Nepal. 
Table 2. Current pest management practices among vegetable growers in Chitwan, Nepal.

\begin{tabular}{|c|c|c|c|}
\hline Group & Frequency $(\%)$ & Chi-Square & $p$-Value \\
\hline \multicolumn{2}{|l|}{ Pest management methods used } & 233.1 & $<0.001$ \\
\hline Cultural & 1 & & \\
\hline Biological & 1 & & \\
\hline Mechanical & 2 & & \\
\hline Chemical & 80 & & \\
\hline $\begin{array}{l}\text { Combination with } \\
\text { chemicals }\end{array}$ & 16 & & \\
\hline \multicolumn{2}{|l|}{ Crop-wise pesticide use } & 130.82 & $<0.001$ \\
\hline Cereal & 11 & & \\
\hline Vegetable & 87 & & \\
\hline Oilseed & 2 & & \\
\hline \multicolumn{2}{|l|}{ Decision for pesticide spray } & 58.8 & $<0.001$ \\
\hline $\begin{array}{l}\text { Before pest } \\
\text { appearance }\end{array}$ & 18 & & \\
\hline $\begin{array}{l}\text { Just after pest } \\
\text { appearance }\end{array}$ & 54 & & \\
\hline $\begin{array}{l}\text { After seeing major } \\
\text { damage }\end{array}$ & 1 & & \\
\hline $\begin{array}{l}\text { Before or after pest } \\
\text { appearance }\end{array}$ & 27 & & \\
\hline
\end{tabular}

Vegetable growers in the study area did not appear to follow the economic threshold values in making spray decisions. The majority of the farmers (54\%) sprayed pesticides immediately after the first appearance of insect pests, while $18 \%$ farmers used pesticide even before the arrival of the pest. Some farmers $(27 \%)$ responded that they make their spray decision (spraying before or after the pest arrival) based on the nature of the pest and the crop grown (Table 2). These prophylactic sprays by most of the farmers might be due to the lack of proper knowledge and information about pest biology and economic threshold. Applications of pesticide even before the appearance of pests in the field ultimately leads to unnecessary expenses [6,27] and pesticide overuse. A study in Pakistan [17] reported that the probability of pesticide overuse decreases with increased levels of education and pest management training. However, no significant relationship $(\varrho=-0.02 ; p=0.828)$ was found between education level, and pesticide use frequency in this study.

\subsection{Pesticide Use Pattern and Safety Practices to Prevent Pesticide Exposure}

About $37 \%$ farmers applied pesticides more than six times, $21 \%$ applied four to six times, $38 \%$ applied one to three times per season, while $4 \%$ did not use pesticide (Table 3 ). Although the frequency of pesticide application depends on the targeted pest and crop, the survey intended to obtain general baseline information and a trend. A similar finding was reported in Bhaktapur, Nepal [26], in which majority of the farmers apply pesticide four times per season irrespective of the pest infestation status. Nearly $84 \%$ of farmers used Agro-vet (pesticide retailers) recommended pesticide rates instead of following the label rate (Table 3). The Government of Nepal has an established agricultural extension system at district and local levels to provide technical service about crop production and protection. However, the majority of the farmers (55\%) were found dependent on Agro-vets for the technical help for overall pest and disease management (Table 4). A previous study [5] also reported that the Agro-vets were the primary sources of information regarding selection and other information on pesticide use. The Agro-vet employees, in general, have no technical background, the information received from them is misleading in many instances. Also, these are private for-profit companies; there might be a conflict of interest in teaching the best method of control and sale of their product. 
Table 3. Pesticide use patterns among vegetable growers in Chitwan, Nepal.

\begin{tabular}{|c|c|c|c|}
\hline Group & Frequency $(\%)$ & Chi-Square & $p$-Value \\
\hline Frequency of pesticide use per season & & 30.8 & $<0.001$ \\
\hline No application & 4 & & \\
\hline 1-3 times & 38 & & \\
\hline $4-6$ times & 21 & & \\
\hline$>6$ times & 37 & & \\
\hline Pesticide use rate & & 186.96 & $<0.001$ \\
\hline $1-2 \mathrm{~mL} / \mathrm{L}$ water & 9 & & \\
\hline $2 \mathrm{~mL} / \mathrm{L}$ water & 6 & & \\
\hline$>2 \mathrm{~mL} / \mathrm{L}$ water & 1 & & \\
\hline Agro-vet recommendation & 84 & & \\
\hline Personal protective equipment uses & & 21.68 & $<0.001$ \\
\hline Mask only & 34 & & \\
\hline Combination & 52 & & \\
\hline No use at all & 14 & & \\
\hline Source of technical information & & 55.44 & $<0.001$ \\
\hline DADO/Extension Service Centers & 11 & & \\
\hline Agro-vets & 55 & & \\
\hline Leader farmers & 8 & & \\
\hline Self & 26 & & \\
\hline Waiting period followed by growers (PHI) & & 82.64 & $<0.001$ \\
\hline Less than 3 days & 25 & & \\
\hline $4-7$ days & 62 & & \\
\hline $8-12$ days & 9 & & \\
\hline 13-16 days & 4 & & \\
\hline Disposal of pesticide containers & & 75.60 & $<0.001$ \\
\hline Collect, bury, and burning & 61 & & \\
\hline Sold to kabadi & 22 & & \\
\hline Canal and water bodies & 4 & & \\
\hline Keep at safe place & 13 & & \\
\hline Protecting bees and pollinators during spray & & 257.70 & $<0.001$ \\
\hline Spraying after 4 p.m. & 9 & & \\
\hline Spraying before flowering stage & 2 & & \\
\hline Spraying safe pesticides & 2 & & \\
\hline Do not consider & 84 & & \\
\hline Others & 3 & & \\
\hline
\end{tabular}

Table 4. Common practices, strategies to reduce chemical exposure, and technical know-how of pesticide application among commercial vegetable growers in Chitwan, Nepal.

\begin{tabular}{|c|c|c|c|c|}
\hline \multirow{2}{*}{ Category } & \multicolumn{2}{|c|}{ Frequency (\%) } & \multirow{2}{*}{ Chi-Square } & \multirow{2}{*}{$p$-Value } \\
\hline & Yes & No & & \\
\hline Read and follow pesticide label & 66 & 34 & 10.24 & 0.001 \\
\hline Understand toxicity label (color code) & 56 & 44 & 1.44 & 0.230 \\
\hline Understand modes of action (MoA) classification & 31 & 69 & 1.44 & 0.230 \\
\hline Know potential adverse health effects of pesticide & 88 & 12 & 57.76 & $<0.001$ \\
\hline Repeated use of same active ingredients & 49 & 51 & 0.04 & 0.841 \\
\hline Use of personal protective equipment and clothes & 86 & 14 & 51.84 & $<0.001$ \\
\hline Knowledge of the preharvest interval (PHI) & 92 & 8 & 70.56 & $<0.001$ \\
\hline Training received on pest management & 17 & 83 & 43.56 & $<0.001$ \\
\hline Technical advice before pesticide application & 83 & 17 & 43.56 & $<0.001$ \\
\hline Knowledge of integrated pest management (IPM) & 34 & 66 & 10.24 & 0.001 \\
\hline Know about the beneficial insects and pollinator & 46 & 54 & 0.64 & 0.424 \\
\hline Following IPM in crop production & 14 & 86 & 51.84 & $<0.001$ \\
\hline Follow crop rotation & 61 & 39 & 4.84 & 0.028 \\
\hline
\end{tabular}

Pesticide label reading and following instructions during application are important for safe handling. The majority of farmers ( $88 \%$ ) were aware of potential adverse effects of pesticides, while the remaining $12 \%$ were unaware of those risks and harmful effects. Similar results had been reported in a 
previous study [17] in which $12.3 \%$ of the surveyed growers in Pakistan responded that pesticides do not pose any risk at all. About $34 \%$ farmers read label before pesticide application. Fifty-six percent of them understand it and 31\% had some knowledge on pesticide mode of action and its importance, but lacked knowledge on its safe use (Table 3) [25]. Only 16\% of farmers in their study correctly know the pesticide toxicity color codes printed on the label. Poor knowledge of pesticide handling and pest management had resulted the use of the same pesticide repeatedly without considering pesticide resistance issues. About half of the respondents (49\%) use the same pesticide repeatedly within same growing season to control target pest (Table 3). Besides, relatively prohibitive costs of new insecticides, lack of diversity of pesticide active ingredients, and poor understanding of resistance management might have contributed to the repeated use of the same pesticide, leading pesticide resistance.

Despite poor knowledge on pesticide label and pesticide characteristics, many farmers $(86 \%)$ used a form of personal protective equipment (PPE) while handling pesticides. Out of a total survey population, 34\% farmers used a mask, and 52\% used facemask along with other PPE like gloves, long sleeve clothes, shoes, or all of them. However, the quality and suitability of the PPE is unknown. Different pesticide labels have unique requirements for PPE. Farmers in Chitwan had no access to any type of PPE that was required for spraying a variety of chemical pesticides. About $14 \%$ farmers did not use any form of PPE (Table 4). A similar study [28] reported that about $30 \%$ of vegetable farmers in Nepal do not use any form of PPE. This issue is common in other developing countries. More than 50\% farmers do not use any form of PPE during pesticide sprays in Iran [29]. Although consumption of pesticides in developing countries is less than the developed and industrialized countries, pesticide poisoning cases are more prevalent in developing countries [30]. This scenario is very serious when it comes to the farmers and field workers' exposure to the pesticides. PPE is the safety equipment required to reduce pesticide exposure. Pesticide handlers should know all potential hazards of the chemical pesticides and should wear appropriate, leak-proof, and well-maintained protective equipment.

Even with a large gap on dissemination of technical information, most of the farmers $(92 \%)$ surveyed were aware of the concept of the pre-harvest interval (PHI) (Table 4), although how effectively they follow PHI from the pesticide label is unknown. The PHI is a legal time to wait before harvesting a crop after applying a particular pesticide to a particular crop. PHI information should be included on all pesticide labels. Most farmers (62\%) in our survey responded that they follow four to seven days PHI, while $25 \%$ farmers follow three days or less (Table 3). A previous study [31] reported that majority of farmer surveyed in Chitwan harvested crops in PHI of one to three days. Harvesting produce without following PHI requirements likely leads to higher pesticide residues on harvested produce which might have serious health consequences for consumers. An elevated level of pesticide residues was found in root and leafy vegetables grown for commercial market in Nepal [28]. A separate study [32] reported that residues of two commonly used active ingredients (dichlorvos and methyl parathion) exceeded the maximum residue limit (MRL) in 5 out of 33 vegetables evaluated. Further, estimated average daily intake exceeded the acceptable daily intake in $\sim 54 \%$ vegetables tested for dichlorvos and $\sim 30 \%$ vegetables tested for methyl parathion [32], both chemicals are highly toxic and banned to use in agriculture in many countries.

While more than $60 \%$ farmers collected and burned or buried pesticide containers after use or kept in a safe place (13\%), some farmers (22\%) sold pesticide containers to recycling centers ("kabadi"), and less than $5 \%$ of farmers dumped those containers in canals and water bodies (Table 3). A study conducted in two rural farming areas in China reported that farmers dispose remnant pesticides into sensitive places such as public lands and water sources [18].

\subsection{Concept of Integrated Pest Management (IPM)}

Concerning knowledge of farmers on integrated pest management (IPM), 34\% of farmers knew about IPM. However, only $14 \%$ of the farmers have been adopting some forms of IPM (Table 4). Beneficial insects, such as predators and parasites, are vital components of IPM. While only $1 \%$ farmers 
followed biological pest control measures, $46 \%$ responded that they know the importance of beneficial insects and pollinators in vegetable production (Table 4). Most of the farmers (84\%) did not consider precautions to prevent harmful effects of pesticides to non-target beneficial insects and pollinators during pesticide spraying. Only $9 \%$ of respondents sprayed pesticides after 4 p.m. to reduce pesticide effects on bees and other non-targets (Table 4). About 61\% farmers grew the same crop one after another, mainly due to small land holding and a lack of knowledge on the importance of crop rotation in insect pest management (Table 4). Moreover, most farmers (83\%) responded that they had never received an opportunity to participate in any technical seminar or workshops related to the pest management (Table 4). A similar communication gap on information exchange has been reported between government extension workers and farmers in Rupendehi district [9], where nearly 98\% of farmers had no training related to agrochemical use.

Despite the implementation of national IPM Training Program (Farmers Field School) since the mid-1990s in Nepal, low adoption of IPM practices suggests a communication gap among government extension organizations, related agencies, and farmers. This scenario clearly showed a need for education and training programs for farmers and government employees through community or other forms of IPM programs [6,30]. Pesticide education programs such as extension training, workshops, and community engagements have proven to be effective in elevating farmers' knowledge in adopting improved pest management practices in other countries [33,34]. The lower adoption of IPM practices in Nepal could be attributed by several factors such as limited availability of insect monitoring and control options, lack of sufficient knowledge and confidence in non-chemical pest control measures, inadequate government pesticide regulation enforcement, and a large gap in information sharing between extension workers and farmers [21,28-31]. Adoption of agricultural practices not only depends on a lack of awareness, but also other agronomic and local farm-related factors such as farm structure, cropping pattern, risk attitudes, and economic burden [35]. Extension agencies should consider these factors before making plans during launching any extension program [36]. Understanding risks that farmers currently face are critical in implementing a holistic IPM approach that minimizes farmer' exposure to pesticides, and ultimately improve their agricultural production.

\section{Conclusions}

Insect, pest, and disease management are primary constraints to commercial vegetable production in developing countries such as Nepal. Farmers use chemical pesticide as an effective pest control measure. The current study aimed to assess farmers' knowledge on pesticide use and handling, and evaluate their current pest management practices in commercial vegetable production. The study found that most of the farmers' knowledge on several aspects of a pesticide such as its use, types, characteristics, selection, and overall handling is very limited. Improper handling and indiscriminate use of pesticides can increase health-related risks and expenses to both farmers and consumers. Farmers use chemical pesticides without considering insect pest monitoring and economic thresholds, pesticide label instructions, pre-harvest interval requirement, proper use of personal protective equipment and clothing, potential impact on non-targets and the environment, which collectively form the basis of IPM. The influence of the government agricultural extension program on improving farmer's knowledge on pesticide use appears inadequate, and farmers solely depend on local pesticide retailers for technical guidance. Poor pesticide safety and use situations are attributable to weak pesticide regulatory and enforcement systems. This study also emphasized the importance of understanding farmers' local situations and educating farmers on several aspects of pesticide use, disposal, and consequences of improper and illegal use. This information will guide policymakers to prioritize their programs and appropriately enforce the sale and use of chemical pesticides to mitigate all environment and health-related consequences. Solving such issues requires a coordinated effort of all stakeholders-farmers, private pesticide retailers, and consultants; government extension agencies at both national and local levels; and other pesticide enforcement agencies. 
Acknowledgments: The authors gratefully acknowledge the Trellis Fund, Horticulture Innovation Lab, and United States Agency for International Development (USAID) for providing funding for this study. We thank all farmers participating in the survey, and thank members and volunteers from the Center for Agricultural Research and Development (CARD-Nepal) for their help with the survey and working with farmers.

Author Contributions: J.P.R., R.G. and K.D.P. designed the study. R.R. and S.P. collected the data. J.P.R. and R.R. analyzed the data and wrote the manuscript. R.G., S.G., and K.D.P. contributed in improving the manuscript. R.G. contributed to improving the discussion section.

Conflicts of Interest: The authors declare no conflict of interest.

\section{References}

1. Gulati, A.; Minot, N.; Delgado, C.; Bora, S. Growth in high-value agriculture in Asia and emergence of vertical link with farmers. In Global Supply Chains, Standards and the Poor; Swinnen, J.F.M., Ed.; CABI International: London, UK, 2007; pp. 91-108.

2. Kaini, B.R. Agro Dream. Republica. Available online: http://admin.myrepublica.com/opinion/story/ 31657 /agro-dream.html (accessed on 13 May 2017).

3. Ministry of Agricultural Development (MOAD). Statistical Information on Nepalese Agriculture 2013/14; Agri-Business Promotion and Statistics Division, Ministry of Agricultural Development, Singha Durbar: Kathmandu, Nepal, 2010.

4. Vaidya, A.; Oli, N.; Aryal, U.R.; Karki, D.B.; Krettek, A. Disparities in fruit and vegetable intake by Socio-demographic characteristics in peri-urban Nepalese adults: Findings from the Heart-health Associated Research and Dissemination in the Community (HARDIC) Study, Bhaktapur, Nepal. J. Kathmandu Med. Coll. 2013, 2, 3-11.

5. Rijal, J.P.; Malla, R.K.; Rawat, P.R.; Tiwari, S.; GC, Y.D. A preliminary study on the practices of insect pest management at Sukranagar VDC, Chitwan. In Proceedings of the National IPM Workshop of Plant Protection Society of Nepal, Lalitpur, Nepal, 25-26 August 2006; KC, G.K., Pokhrel, S., Upadhaya, N.S., Marahatta, S.P., Bhandari, B.D., Eds.; Plant Protection Society of Nepal: Lalitpur, Nepal, 2006; pp. 297-307.

6. Atreya, K. Pesticide use knowledge and practices: Gender differences in Nepal. Environ. Res. 2007, 104, 305-311. [CrossRef] [PubMed]

7. Sharma, D.R.; Thapa, R.B.; Manandhar, H.K.; Shrestha, S.M.; Pradhan, S. Use of pesticides in Nepal and impacts on human health and environment. J. Agric. Environ. 2012, 13, 67-74. [CrossRef]

8. Central Bureau of Statistics (CBS). National Sample Census of Agriculture, Nepal, 2002/03: Highlights; Government of Nepal (Kathmandu); National Planning Commission and Central Bureau of Statistics: Kathmandu, Nepal, 2009.

9. Bhandari, G. An overview of agrochemicals and their effects on the environment in Nepal. Appl. Ecol. Environ. Sci. 2014, 2, 66-73. [CrossRef]

10. Stern, V.M.; Smith, R.F.; van den Bosch, R.; Hagen, K.S. The integrated control concept. Hilgardia 1959, 29, 81-101. [CrossRef]

11. Pimentel, D.; Acquay, H.; Biltonen, M.; Rice, P.; Silva, M.; Nelson, J.; Lipner, V.; Giordano, S.; Horowitz, A.; D'Amore, M. Assessment of Environmental and Economic Impacts of Pesticide Use. In The Pesticide Question: Environment, Economics, and Ethics; Pimentel, D., Lehman, H., Eds.; Chapman and Hall: New York, NY, USA, 1993; pp. 47-84.

12. Wesseling, C.; Aragón, A.; Castillo, L.; Corriols, M.; Chaverri, F.; Cruz, E.D.; Keifer, M.; Monge, P.; Partanen, T.J.; Ruepert, C.; et al. Hazardous pesticides in Central America. Int. J. Occup. Environ. Health 2001, 7, 287-294. [CrossRef] [PubMed]

13. Ecobichon, D.J. Pesticide use in developing countries. Toxicology 2001, 160, 27-33. [CrossRef]

14. Van der Maden, E.; Wulansari, M.; Koomen, I. Occupational Pesticide Exposure in Vegetable Production-A Literature and Policy Review with Relevance to Indonesia; Wageningen University \& Research Centre: Wageningen, The Netherlands, 2014; Volume 2, 54p.

15. Shrestha, P.L.; Neupane, F.P. Socio-economic contexts on pesticide use in Nepal. Landschaftsökologie und Umweltforschung 2002, 38, 205-223.

16. Yassin, M.M.; Mourad, T.A.; Safi, J.M. Knowledge, attitude, practice, and toxicity symptoms associated with pesticide use among farm workers in the Gaza Strip. Occup. Environ. Med. 2015, 59, 387-393. [CrossRef] 
17. Khan, M.; Mahmood, H.Z.; Damalas, C.A. Pesticide use and risk perceptions among farmers in the cotton belt of Punjab, Pakistan. Crop Prot. 2015, 67, 184-190. [CrossRef]

18. Yang, X.; Wang, F.; Meng, L.; Zhang, W.; Fan, L.; Geissen, V.; Ritsema, C.J. Farmer and retailer knowledge and awareness of the risks from pesticide use: A case study in the Wei River catchment, China. Sci. Total Environ. 2014, 498, 172-179. [CrossRef] [PubMed]

19. Plianbangchang, P.; Jetiyanon, K.; Wittaya-areekul, S.; Resources, N. Pesticide use patterns among small-scale farmers: A case study from Phitsanulok, Thailand. Southeast Asian J. Trop. Med. Public Health 2007, 40, 401-410.

20. Yadav, I.C.; Linthoingambi, N.; Hussain, J.; Cheng, Z.; Li, J.; Zhang, G.; Jones, K.C. Current status of persistent organic pesticides residues in air, water, and soil, and their possible effect on neighboring countries: A comprehensive review of India. Sci. Total Environ. 2015, 511, 123-137. [CrossRef] [PubMed]

21. Schreinemachers, P.; Afari-Sefa, V.; Heng, C.H.; Dung, P.T.M.; Praneetvatakul, S.; Srinivasan, R. Environmental science and policy safe and sustainable crop protection in Southeast Asia: Status, challenges and policy options. Environ. Sci. Policy 2015, 54, 357-366. [CrossRef]

22. District Agriculture Development Office (DADO). Annual Report 2006; District Agriculture Development Office: Bharatpur, Chitwan, Nepal, 2006.

23. District Development Committee. District Climate and Energy Plan of Chitwan District. 2014; 85p. Available online: http:/ / ddcchitwan.gov.np/wp-content/uploads/2015/09/District-Climate-and-EnergyPlan-Chitwan.pdf (accessed on 17 December 2017).

24. Damalas, C.A.; Hashemi, S.M. Pesticide risk perception and use of personal protective equipment among young and old cotton growers in northern Greece. Agrociencia 2010, 44, 363-371.

25. Mainali, R.P.; Thapa, R.B.; Tiwari, S.; Pokhrel, P.A.; Ansari, A.R. Knowledge and practices on eggplant fruit and shoot borer, Leucinodes orbonalis Guenee management in Dhading and Bara districts of Nepal. Albanian J. Agric. Sci. 2010, 13, 6-13.

26. Jha, R.K.; Regmi, A.P. Pesticides and productivity-A study of vegetable farming in Nepal. SANDEE Policy Brief 2009, 37, 1-4.

27. Atreya, K. Health costs of pesticide use in a vegetable growing area, central mid-hills, Nepal. Himal. J. Sci. 2005, 3, 81-83. [CrossRef]

28. Koirala, P.; Tamrakar, A.S.; Bhattarai, B.P.; Yadav, B.K.; Humagain, S.; GC, Y.D. Use and handling practice of pesticides in vegetables: A case study on some selected districts of Nepal. J. Food Sci. Technol. Nepal 2010, 6, 105-109. [CrossRef]

29. Hashemi, S.M.; Rostami, R.; Hashemi, M.K.; Damalas, C.A. Pesticide use and risk perceptions among farmers in Southwest Iran. Hum. Ecol. Risk Assess. 2012, 18, 456-470. [CrossRef]

30. Winrock International. Knowledge-based integrated sustainable agriculture and nutrition (Kisan) project. In Pesticide Evaluation Report and Safer Use Action Plan (PERSUAP), 2014, Version 5; Winrock International: Little Rock, AR, USA, 2014.

31. Regmi, R.; Tiwari, S.; Thapa, R.B.; KC, G.B. Ecofriendly management of spotted pod borer (Maruca vitrata) on yard-long bean in Chitwan Nepal. Int. J. Res. 2014, 1, 386-394.

32. Rawal, D.S.; Rana, N.; Shrestha, S.; Sijapati, J. Assessment of pesticide residues in some vegetables grown in Kavrepalanchok and Bhaktapur districts. Nepal J. Sci. Tech. 2012, 13, 45-50. [CrossRef]

33. Damalas, C.A.; Koutroubas, S.D. Farmers' training on pesticide use is associated with elevated safety. Toxics 2017, 5, 19. [CrossRef] [PubMed]

34. Allahyari, M.S.; Damalas, C.A.; Ebadattalab, M. Farmers' technical knowledge about integrated pest management (IPM) in olive production. Agriculture 2017, 7, 101. [CrossRef]

35. Calliera, C.; Berta, F.; Galassi, T.; Mazzini, F.; Rossi, R.; Bassi, R.; Meriggi, P.; Bernard, A.; Marchis, A.; Di Guardo, A.; et al. Enhance knowledge on sustainable use of plant protection products within the framework of the Sustainable Use Directive. Pest Manag. Sci. 2013, 69, 883-888. [CrossRef] [PubMed]

36. Ríos-González, A.; Jansen, K.; Sánchez-Pérez, H.J. Pesticide risk perceptions and the differences between farmers and extensionists: Towards a knowledge-in-context model. Environ. Res. 2013, 124, 43-53. [CrossRef] [PubMed]

(C) 2018 by the authors. Licensee MDPI, Basel, Switzerland. This article is an open access article distributed under the terms and conditions of the Creative Commons Attribution (CC BY) license (http:/ / creativecommons.org/licenses/by/4.0/). 